\title{
Differences in Anthropometric Characteristics among Junior Soccer and Volleyball Players
}

\author{
Bojan Masanovic ${ }^{1}$, Dusko Bjelica ${ }^{1}$, Marin Corluka ${ }^{2}$ \\ 'University of Montenegro, Faculty for Sport and Physical Education, Niksic, Montenegro, ${ }^{2}$ University of Mostar, Faculty of Mathematics and Science \\ Education, Mostar, Bosnia and Herzegovina
}

\begin{abstract}
The aim of this study was to obtain the relevant knowledge about significant differences in some anthropometric characteristics of junior soccer and volleyball players. The sample included 39 male subjects divided into two subsamples, 25 soccer players and 14 volleyball players. The variables sample included 20 anthropometric measures that defined longitudinal and transversal dimensionality of skeleton, volume and mass of the body, and subcutaneous adipose tissue. The results were analysed in a statistical procedure marked as a significance testing of two arithmetic means of the independent samples, a t-test at the level of significance of $p<0.05$. It was concluded, based on these results, that significant differences occur in body height, body weight, elbow diameter, wrist diameter, ankle joint diameter, lower arm circumference (max), lower leg circumference (max) and abdomen skinfold, while the significant difference does not occur in knee diameter, upper arm circumference (min), upper arm circumference (max), lower arm circumference (min), upper leg circumference (min), upper leg circumference (max), lower leg circumference (min), upper arm skinfolf, lower arm skinfold, thigh skinfold, calf skinfold and chest skinfold. Therefore, these findings may give coaches from the region better working knowledge and suggest them to follow recent selection process methods and to be more careful during the process of talent identification.
\end{abstract}

Key words: Anthropometric Measurement, Different Sports, Junior League

\section{Introduction}

Athletes, competing in different sports, differ in their physical and physiological characteristics (Stojanovic et al., 2016; Morteza Tayebi, Mahmoudi, Shirazi, \& Sangi, 2017; Spaic, Vukasevic, \& Masanovic, 2018). Elite sports require that the body performs at the optimal biomechanical and physiological capacity (Bajramovic, Talovic, Alic, \& Jeleskovic, 2008; Arifi, Bjelica, \& Masanovic, 2019; Saavedra et al., 2018). Accordingly, from junior athlete competing in the strongest leagues in his age group is expected to have the optimal morphology, strength, and endurance for the functional requirements of the sport in question (Mašanović, Vukotić, Popović, \& Bjelica, 2018). Morphological characteristics are present in the equation of the specification of almost every sport (Bjelica, Popovic, $\&$ Gardasevic, 2016a) so they are of great importance when it comes to orientation and selection in all sports. Since the primarily, due to the development of technique and tactics, coefficients of participation of some morphological dimensions in the equation of the specification are constantly changing, for the effective talent's identification and the efficient conduction of transformational procesess, the continuous involvement of sports science and practice is required (Popovic, Smaic, Joksimovic, \& Masanovic, 2010; Bjelica \& Fratric, 2011; Bjelica, 2013; Bjelica, Popovic, \& Gardasevic, 2016a).

According to previous studies, successful participation in both soccer and volleyball games, requires a high level of technical and tactical skills, and also requires suitable anthropometrical characteristics and body composition from each athlete (Hurst et al., 2017; Masanovic, Popovic, \& Bjelica, 2018). Of course, the demands of these two sports are very different

\section{Montenegro}

Sport

\section{Correspondence:}

B. Masanovic

University of Montenegro, Faculty for Sport and Physical Education, Narodne omladine bb, 81400 Niksic, Montenegro

E-mail: bojanma@ucg.ac.me 
(Popovic, Akpinar, Jaksic, Matic, \& Bjelica, 2013; Popovic, Bjelica, Jaksic, \& Hadzic, 2014). Soccer is a team sport which is played on an open field of great dimensions, and therefore requires a high standard of physical preparation, it is also based on a large number of movements, and a series of moderate activities that periodically replace high intensity activities, leading to significant metabolic heat production, and an intensity of $75-90 \%$ of the maximum heart rate, or $70-80 \%$ of the maximum oxygen consumption (Rexhepi \& Brestovci, 2010; Sæther, 2017; Amani, Sadeghi, \& Afsharnezhad, 2018). On the other hand, in volleyball, the patterns of movement differ greatly compared to soccer, the basic elements of the game are spiking, jumping, power hitting and blocking. In vooleyball the dominance over the net becomes the most decisive factor for victory (Laporta, Nikolaidis, Thomas, \& Afonso, 2015; Masanovic, Milosevic, \& Corluka, 2018). The top-level volleyball players do not have $\mathrm{VO} 2$ max values on the high level as endurance trained elite players in soccer.

The aim of this research is to describe the morphological profile of young soccer and volleyball players, to determine if here is a difference in anthropometric dimensions between them, and to define its scale.

\section{Methods}

The sample included 39 male subjects divided into two subsamples. The first subsample included 25 soccer players $(16.64 \pm 0.49$ yrs.), who trained in the junior selection in the Soccer club "Vojvodina" from Novi Sad, which competed in Serbian Junior League, while the other subsample included 15 volleyball players (17.36 \pm 0.74 yrs.), who trained in the junior selection in the Volleyball club "Vojvodina" from Novi Sad, which competed also in Serbian Junior League. Criteria for selection of subjects for the sample were as follows: that they have been members of the first team squad for at least one year, and that they are in good health.

Anthropometric research technique was used for data collection. A total of 20 anthropometric measures were evalua- ted, that defined the longitudinal and transversal dimensionality of skeleton, body volume and body mass, and subcutaneous adipose tissue: body height, body weight, elbow diameter, wrist diameter, knee diameter, ankle joint diameter, minimum circumference of the upper arm, maximum circumference of the upper arm, minimum circumference of the forearm, maximum circumference of the forearm, minimum circumference of the upper leg, maximum circumference of the upper leg, minimum circumference of the lower leg, maximum circumference of the lower leg, skinfold thickness of the upper arm, skinfold thickness of the forearm, skinfold thickness of the thigh, skinfold thickness of the calf, skinfold thickness of the chest and skinfold thickness of the abdomen.

Anthropometric research was conducted according to IBP standards, while respecting the basic rules and principles related to the selection of parameters, standard conditions and measuring techniques, as well as the standard measuring instruments calibrated before measuring.

The measuring was carried out in the middle of the competitive season. The data obtained in the research were analyzed with the statistical program SPSS 20.0, adapted for use on personal computers. The arithmetic mean, standard deviation and standard errors of the arithmetic mean of the anthropometric characteristics were calculated for respondents who are professional soccer players and professional volleyball players, by testing the differences of arithmetic means of independent samples at a significance level of $\mathrm{p}<0.05$. This analysis gave answer to the question whether there is a difference, and the scope of it, between the anthropometric characteristics of the soccer and volleyball players, regulars who compete in union divisions.

\section{Results}

This section presents the results of central tendency and dispersion parameters, as well as the results of t-test for independent samples, classified into tables.

Tabela 1. Descriptive Data of 39 males enrolled in the study

\begin{tabular}{|c|c|c|}
\hline & Soccer $(N=25), A M \pm S D$ & Volleyball $(\mathrm{N}=14), \mathrm{AM} \pm \mathrm{SD}$ \\
\hline Body height $(\mathrm{cm})$ & $177.80 \pm 6.63$ & $194.28 \pm 5.30$ \\
\hline Bodyweight (kg) & $69.90 \pm 6.78$ & $82.04 \pm 8.58$ \\
\hline Elbow diameter (mm) & $70.60 \pm 3.17$ & $75.69 \pm 3.85$ \\
\hline Wrist diameter (mm) & $55.67 \pm 2.87$ & $59.69 \pm 3.71$ \\
\hline Knee diameter (mm) & $99.74 \pm 4.02$ & $97.81 \pm 4.79$ \\
\hline Ankle joint diameter (mm) & $72.20 \pm 2.25$ & $74.00 \pm 3.00$ \\
\hline Upper arm circumference (min) (cm) & $27.62 \pm 1.90$ & $28.68 \pm 1.88$ \\
\hline Upper arm circumference (max) (cm) & $29.54 \pm 2.12$ & $30.57 \pm 1.88$ \\
\hline Lower arm circumference (min) (cm) & $16.96 \pm 0.84$ & $16.82 \pm .70$ \\
\hline Lower arm circumference (max) (cm) & $24.84 \pm 1.18$ & $25.72 \pm 1.44$ \\
\hline Upper leg circumference (min) (cm) & $39.80 \pm 2.38$ & $40.90 \pm 2.30$ \\
\hline Upper leg circumference (max) (cm) & $54.04 \pm 3.63$ & $56.11 \pm 3.36$ \\
\hline Lower leg circumference $(\mathrm{min})(\mathrm{cm})$ & $23.64 \pm 1.04$ & $24.25 \pm 2.02$ \\
\hline Lower leg circumference (max) (cm) & $35.46 \pm 1.81$ & $37.46 \pm 1.99$ \\
\hline Upper arm skinfolf (mm) & $4.82 \pm 1.29$ & $5.29 \pm 1.12$ \\
\hline Lower arm skinfold (mm) & $5.65 \pm 1.65$ & $6.21 \pm .90$ \\
\hline Thigh skinfold (mm) & $9.40 \pm 3.23$ & $11.19 \pm 3.53$ \\
\hline Calf skinfold (mm) & $8.10 \pm 2.32$ & $7.98 \pm 1.58$ \\
\hline Chest skinfold (mm) & $7.18 \pm 1.92$ & $8.39 \pm 2.12$ \\
\hline Abdomen skinfold (mm) & $6.82 \pm 1.99$ & $8.38 \pm 1.94$ \\
\hline
\end{tabular}

Legend: $\mathrm{N}$ - number of Subjects, AM - arithmetic mean, SD - standard deviation 
Observing the results of the central tendency and dispersion parameters of longithudinal and transversal skeletal dimensionality, body volume and body mass of the soccer and volleyball players, we immediately notice that volleyball players have higher value in 18 variables, while in terms of footballers, we notice higher values in only 2 parameters (Table 1).

On the basis of the results presented it was determined that the subsamples are significantly different in 8 out of 20 anthropometric characteristics (level of significance $\mathrm{p}<0.05$ ). It was concluded, based on these results, that significant di- fferences occur in body height, body weight, elbow diameter, wrist diameter, ankle joint diameter, lower arm circumference ( $\max )$, lower leg circumference $(\max )$ and abdomen skinfold, while the significant difference does not occur in knee diameter, upper arm circumference (min), upper arm circumference (max), lower arm circumference (min), upper leg circumference (min), upper leg circumference (max), lower leg circumference (min), upper arm skinfolf, lower arm skinfold, thigh skinfold, calf skinfold and chest skinfold. For each of the parameters in which a significant difference has been found, higher values can be seen in volleyball players (Table 2).

Tabela 2. Difference between junior soccer and volleyball players tested by Independent t-test

\begin{tabular}{lcccccccc}
\hline & $\mathrm{F}$ & $\mathrm{T}$ & $\mathrm{Df}$ & $\mathrm{Sig}$ & $\mathrm{MD}$ & $\mathrm{SED}$ & Min & Max \\
\hline Body height & .68 & -7.96 & 37 & .000 & -16.47 & 2.07 & -20.66 & -12.28 \\
Bodyweight & .15 & -4.80 & 37 & .000 & -12.14 & 2.30 & -17.26 & -7.02 \\
Elbow diameter & .92 & -4.45 & 37 & .000 & -5.08 & 1.14 & -7.40 & -2.77 \\
Wrist diameter & .38 & -3.76 & 37 & .001 & -4.01 & 1.07 & -6.17 & -1.85 \\
Knee diameter & .33 & 1.34 & 37 & .188 & 1.92 & 1.44 & -.98 & 4.84 \\
Ankle joint diameter & .08 & -2.13 & 37 & .004 & -1.80 & .85 & -3.52 & -.08 \\
Upper arm circumference (min) & .99 & -1.68 & 37 & .102 & -1.06 & .63 & -2.34 & .22 \\
Upper arm circumference (max) & .71 & -1.52 & 37 & .138 & -1.03 & .68 & -2.41 & .35 \\
Lower arm circumference (min) & .57 & .52 & 37 & .604 & .14 & .26 & -.40 & .67 \\
Lower arm circumference (max) & .16 & -2.05 & 37 & .047 & -.88 & .43 & -1.73 & -.01 \\
Upper leg circumference (min) & .83 & -1.39 & 37 & .172 & -1.09 & .78 & -2.68 & .50 \\
Upper leg circumference (max) & .69 & -1.75 & 37 & .088 & -2.07 & 1.18 & -4.46 & .32 \\
Lower leg circumference (min) & .06 & -1.25 & 37 & .218 & -.61 & .49 & -1.60 & .38 \\
Lower leg circumference (max) & .53 & -3.21 & 37 & .003 & -2.00 & .62 & -3.27 & -.74 \\
Upper arm skinfolf & .51 & -1.13 & 37 & .267 & -.46 & .41 & -1.30 & .37 \\
Lower arm skinfold & .24 & -1.19 & 37 & .243 & -.57 & .48 & -1.53 & .40 \\
Thigh skinfold & .52 & -1.60 & 37 & .118 & -1.78 & 1.12 & -4.05 & .47 \\
Calf skinfold & .11 & .170 & 37 & .863 & .12 & .70 & -1.30 & 1.54 \\
Chest skinfold & .41 & -1.83 & 37 & .076 & -1.22 & .67 & -2.56 & .13 \\
Abdomen skinfold & .87 & -2.37 & 37 & .023 & -1.56 & .66 & -2.89 & -.22 \\
\hline
\end{tabular}

Legend: F-value of Levene's test of equality of variances, $t$-value of t-test, df-number of degreeseof freedom, Sig-significance of two-tailed testing of arithmetic mean difference, MD-arithmetic mean difference, SED-standard error of diffeence, Min-the level of lower difference interval, Max-level of upper difference interval

\section{Discussion}

The results of this study show that there are significant differences in certain anthropometric characteristics between soccer players and volleyball players who compete in the elite Serbian Junior Leagues. Volleyball players are significantly higher than soccer players, which is in line with previous research (Popović et al., 2014; Masanovic, T. Bavcevic, \& I. Bavcevic, 2019). If we consider that official statistical data proved that the average body height of all the participants in the FIFA U-17 World Soccer Championship India 2017 was 176.01 centimeters, while the average height of the of all participants in CEV U17 Volleyball European Championship 2017 in Turkey was 189 centimeters, we can conclude that the players from Serbian soccer and volleyball Junior Premier League with average body height 177.8 and 194.28 centimeters are tall enough and they do not lag behind the World top players. Also, the selection process is quality conducted, which is not a surprise, because it is well known that the number of very tall subjects appears to be high in Dinaric Alpes area (Bjelica, Popovic, Kezunovic, Petkovic, Jurak, \& Grasgruber, 2012; Popović, Milašinović, Matić, Gardašević, \& Bjelica, 2016; Popovic, Gardasevic, Masanovic, Arifi,
\& Bjelica, 2017; Masanovic, 2017; Popovic, 2017). The significant body mass difference is not a surprise, as the previous literature indicates a significantly higher body weight of the volleyball players (Ferreira Oliveira, Teixeira Vaz, Pastore, \& João, 2018; Vukotic \& Georgiev, 2019), which is also the logical consequence of a large difference in body height.

Results related to measures of the skeleton transversal showed significantly higher values for volleyball players for 3 out of 4 variables (elbow diameter, wrist diameter, and ankle joint diameter). Knee diameter showed significantly higher values for soccer players, which is no surprise, because the biggest adaptation in football shows just this joint (Isık, Unlu, Gozubuyuk, Aslanyurek, \& Bereceli, 2018). When body volume and subcutaneous adipose tissue are concerned, significantly higher values were shown for volleyball players for 7 out of 8 variables and for 5 out of 6 variables. These results are in line with previous research (Bandyopadhyay, 2007; Sprague, Mokha, \& Gatens, 2014) which is also logical because in research, soccer is recognized as an aerobic sport in which activity lasts longer and running distance is greater (Popovic et al., 2013; Popovic, Masanovic, Molnar, \& Smajic, 2009; Gardasevic, Bjelica, \& Popovic, 2015), which justifies 
somewhat higher value of the thickness of the skin folds. Ultimately, considering the higher values of body height and body mass, values of circumference, are expected primarily as a logical consequence.

Professionalism from athletes requires a high level of preparation, both motoric and functional, which must be supported by morphological characteristics that should correspond, to the specifics of the sports and player position, which differ within almost every sport branch (Bjelica, 2005; Radjo et al., 2016; Gardasevic, Popovic, \& Bjelica, 2016; Vukasevic, Vukotic, \& Masanovic, 2018; Vukasevic, Spaic, Masanovic, 2018).

The goal of this research was to determine whether there is a difference, and what is the scope of it, in anthropometric characteristics between the junior soccer and volleyball players. Also, to characterize, as acurately as possible, the morphological characteristics of subjects. Considering the movement patterns in volleyball, slightly greater body height and body mass are expected primarily for the reason that volleyball is a sport in which body height gives advantage in defence and attack, because taller players have the ability to easily spike the ball over the tall opponent's in defensive block, and vice versa, to set a tall defensive block on the other side of the netthrough, by which opposing attackers have less chance to win points (Smajic et al., 2015; Oliveira, Valladares, Vaz, \& João, 2016). Movement patterns in soccer and volleyball are the reason for higher diameters of the ankle joints in volleyball players, and higher values of knee diameter in soccer player (Calbet, Díaz Herrera, \& Rodríguez, 1999; Fredericson et al., 2007; Zouch et al., 2008; Stanganelli, Dourado, Oncken, Mançan, \& da Costa, 2008). Circumferences are expected as a logical consequence of the difference in the absolute size of the body. Also, movement patterns in soccer are the reason for lower subcutaneous adipose tissue values for soccer players because in research, soccer is recognized as an aerobic sport in which activity lasts longer and running distance is greater (Popovic et al., 2013; Pasa, Vukasevic, \& Masanovic, 2019).

Of great interest for some authors are morphological characteristics of topclass soccer and volleyball players (Marques, \& Marinho, 2009; Gjonbalaj, Georgiev, \& Bjelica, 2018; Krespi, Sporis, \& Popovic, 2019), because the particular morphology profile of an athlete, combined with motor and functional abilities, should express its full potential (Gusic et al. 2017). The results of this study may serve as model parameters for estimating the same variables for other players of the same sport and competition rank, or for comparison with the results of similar research. It should be noted that players who want to compete successfully must have the characteristics established by the standards of that sport, which of course also refers to the morphological quality that players have to possess.

\section{Acknowledgements}

There are no acknowledgements.

\section{Conflict of Interest}

The authors declare that there are no conflicts of interest.

Received: 1 February 2019 | Accepted: 1 March 2019 | Published: 19 April 2019

\section{References}

Amani, A. R., Sadeghi, H., \& Afsharnezhad, T. (2018). Interval training with blood flow restriction on aerobic performance among young soccer players at transition phase. Montenegrin Journal of Sports Science and Medicine, 7(2), 5-10. doi: 10.26773/mjssm.180901

Arifi, F., Bjelica, D., \& Masanovic, B. (2019). Differences in anthropometric characteristics among junior soccer and handball players. Sport Mont, 17(1), 45-49. doi: 10.26773/smj.190208

Bajramovic, l., Talovic, M., Alic, H., \& Jeleskovic, E. (2008). Nivo kvantitativnih promjena specifično-motoriČkih sposobnosti nogometaŠa pod uticajem situacionog treninga. Sport Mont, 6(15-16-17), 104-109.

Bandyopadhyay, A. (2007). Anthropometry and Body Composition in Soccer and Volleyball Players in West Bengal, India. Journal of Physiological Anthropology, 26(4), 501-505.

Bjelica, D. (2005). Sistematizacija sportskih disciplina i sportski trening. Podgorica: Crnogorska sportska akademija.

Bjelica, D. (2013). Teorija sportskog treninga. Podgorica: Univerzitet Crne Gore.

Bjelica, D., \& Fratrić, F. (2011). Sportski trening: teorija, metodika i dijagnostika. Nikšić: Fakultet za sport i fizičko vaspitanje.

Bjelica, D., Popović, S., i Gardašević, J. (2016a). Modeli fizičke pripreme vrhunskih sportaša i doziranje opterećenja. Zbornik radova 14. godišnje međunarodne konferencije "Kondicijska priprema sportaša" (185-189). Zagreb: Udruga kondicijskih trenera Hrvatske.

Bjelica, D., Popović, S., i Gardašević, J. (2016b). Opći principi planiranja i programiranja fizičkih priprema sportaša. Zbornik radova 14. godišnje međunarodne konferencije "Kondicijska priprema sportaša" (190-192). Zagreb: Udruga kondicijskih trenera Hrvatske.

Bjelica, D., Popovic, S., Kezunovic, M., Petkovic, J., Jurak, G., \& Grasgruber, P. (2012). Body Height and Its Estimation Utilizing Arm Span Measurements in Montenegrin Adults. Anthropological Noteboos, 18(2),69-83.

Calbet, J. A. L., Díaz Herrera, P., \& Rodríguez, L. P. (1999). High Bone Mineral Density in Male Elite Professional Volleyball Players. Osteoporosis International, 10(6), 468-474.

Duncan, M.J., Woodfield, L., al-Nakeeb, Y. (2006). Anthropometric and physiological characteristics of junior elite volleyball players. British Journal of Sports Medicine, 40(7), 649-651.

Ferreira Oliveira, A. O. G., Teixeira Vaz, L. M., Pastore, J. C., \& João, P. V. (2018). Discriminate scoring skills and non-scoring skills according to results in the Brazilian men's volleyball SuperLeague. Montenegrin Journal of Sports Science and Medicine, 7(1), 73-79. doi: 10.26773/mjssm.180310

Ferreira Oliveira, A. O. G., Teixeira Vaz, L. M., Pastore, J. C., \& João, P. V. (2018). Discriminate scoring skills and non-scoring skills according to results in the Brazilian men's volleyball SuperLeague. Montenegrin Journal of Sports Science and Medicine, 7(1), 73-79. doi: 10.26773/mjssm.180310

Fredericson, M., Chew, K., Ngo, J., Cleek, T., Kiratli, J., \& Cobb, K. (2007). Regional bone mineral density in male athletes: a comparison of soccer players, runners and controls. British Journal of Sports Medicine, 41(10), 664-668.

Gardasevic, J., Bjelica, D., \& Popovic, S. (2015). The effects of the training in the preparation period on the agility transformation with cadet level football players. Sport Mont, 13(43-44-45),355-60.

Gardašević, J., Popović, S., \& Bjelica, D. (2016). After preparation period ball shooting accuracy at players U15. In Abstract Book of the 8th Conference for Youth Sport (88). Ljubljana: University of Ljubljana, Faculty of Sport.

Gjonbalaj, M., Georgiev, G., \& Bjelica, D. (2018). Differences in Anthropometric Characteristics, Somatotype Components, and Functional Abilities Among Young Elite Kosovo Soccer Players Based on Team Position. Int. J. Morphol., 36(1),41-7.

Gusić, M., Popović, S., Molnar, S., Mašanović, B., \& Radaković, M. (2017) Sport-Specific Morphology Profile: Differences in Anthropometric Characteristics among Elite Soccer and Handball Players. Sport Mont, 15(1),3-6.

Hurst, M., Loureiro, M., Valongo, B., Laporta, L., Nikolaidis, P., \& Afonso, J. (2017). Systemic Mapping of High-Level Women's Volleyball using Social Network Analysis: The Case of Attack Coverage, Freeball, and Downball. Montenegrin Journal of Sports Science and Medicine, 6(1), 57-64.

Isık, A., Unlu, G., Gozubuyuk, O. B., Aslanyurek, T., \& Bereceli, C. (2018). The relationship between previous lower extremity injury, body weight and bilateral eccentric hamstring strength imbalance in young soccer players. Montenegrin Journal of Sports Science and Medicine, 7(2), 23-28. doi: $10.26773 /$ mjssm. 180904

Krespi, M., Sporis, G., \& Popovic, S. (2019). Exponential versus linear tapering in junior elite soccer players: effects on physical match performance according to playing positions. Montenegrin Journal of Sports Science and Medicine, 8(1), Ahead of Print. doi: 10.26773/mjssm.190303

Laporta, L., Nikolaidis, P., Thomas, L., \& Afonso, J. (2015). The Importance of Loosely Systematized Game Phases in Sports: The Case of Attack Coverage Systems in High-Level Women's Volleyball. Montenegrin Journal of Sports Science and Medicine, 4(1), 19-24.

Marques, M.C. \& Marinho, D.A. (2009). Physical parameters and performance values in starters and non-starters volleyball players: A brief research note. Motricidade, 5(3), 7-11. 
Masanovic, B. (2017). Relationship between Arm Span Measurements and Body Height in Dinaric Alpes Population: a Systematic Review. Journa of Anthropology of Sport and Physical Education, 1(1),33-7.

Masanovic, B., Bavcevic, T., \& Bavcevic, I. (2019). Comparative study of anthropometric measurement and body composition between junior soccer and volleyball players from the serbian national league. Sport Mont, 17(1), 9-14. doi: 10.26773/smj.190202

Masanovic, B., Milosevic, Z., \& Corluka, M. (2018). Comparative Study of Anthropometric Measurement and Body Composition between Junio Handball and Volleyball Players from Serbian National League. International Journal of Applied Exercise Physiology, 7(4), 1-6. https://doi. org/10.30472/ijaep.v7i4.313

Masanovic, B., Popovic, S., \& Bjelica, D. (2018). Comparative Study of Anthropometric Measurement and Body Composition Between Junior Socce and Volleyball Players From National League. In Book of Abstracts 15th International Scientific Conference on Transformation Process in Sport "Sport Performance" (58), Podgorica: Montenegrin Sports Academy.

Masanović, B., Vukotić, M., Popović, S., \& Bjelica, D. (2018). Comparative study of anthropometric measurement and body composition between junior basketball and volleyball players from Serbian national league. In Proceedings World Congress of Performance Analysis of Sport XII (340). Opatija: International Society of Performance Analysis of Sport.

Morteza Tayebi, S., Mahmoudi, A., Shirazi, E., \& Sangi, M. (2017). Acute Response of Some Iron Indices of Young Elite Wrestlers to Three Types of Aerobic, Anaerobic, and Wrestling Exercise. Montenegrin Journal of Sports Science and Medicine, 6(1), 5-11.

Oliveira, A., Valladares, N., Vaz, L., \& João, P. (2016). Evaluation of Scoring Skills and Non Scoring Skills in the Brazilian SuperLeague Women's Volleyball. Montenegrin Journal of Sports Science and Medicine, 5(2), 25-31.

Pasa, Y. C., Vukasevic, V., \& Masanovic, B. (2019). Differences in anthropometric characteristics among junior basketball and volleyball players. Journal of Anthropology of Sport and Physical Education, 3(1), 35-39. doi: 10.26773/jaspe.190107

Popovic, S. (2017). Local Geographical Differences in Adult Body Height in Montenegro. Montenegrin Journal of Sports Science and Medicine, 6(1), 81-87.

Popovic, S., Akpinar, S., Jaksic, D., Matic, R., \& Bjelica, D. (2013). Comparative Study of Anthropometric Measurement and Body Composition be tween Elite Soccer and Basketball Players. International Journal of Morphology, 31(2),461-7.

Popović, S., Bjelica, D., Jakšić, D., \& Hadžić, R. (2014). Comparative Study of Anthropometric Measurement and Body Composition between Elite Soccer and Volleyball Players. Int. J. Morphol., 32(1),267-74.

Popovic, S., Gardasevic, J., Masanovic, B., Arifi, F., \& Bjelica, D. (2017). Standing Height and its Estimation Utilizing Foot Length Measurements in Adolescents from Western Region in Kosovo. Sport Mont, 15(3), 3-7.

Popovic, S., Masanovic, B., Molnar, S., \& Smajic, M. (2009). Determining Body Composition of Top Level Athletes. Teme, 33(4), 1534-1549.

Popović, S., Milašinović, R., Matić, R., Gardašević, J., \& Bjelica, D. (2016). Body height and its estimation utilizing arm span measurements in male adolescents from southern region in Montenegro. In Book of Abstracts of the 13th International Scientific Conference on Transformation Process in Sport "Sport Performance" (29-30), Podgorica: Montenegrin Sports Academy.

Popovic, S., Smajic, M., Joksimovic, A., \& Masanovic, B. (2010). The differences in body composition between football players of different rank compe- titions. Sport Mont, 8(23-24),362-7.

Radjo, I., Alic, H., Bajramovic, I., Jeleskovic, E., Covic, N., Likic, S., \& Mekic, A (2016). Functional strength training effects on knee flexors and extensors power output in football players. Sport Mont, 14(2), 13-16.

Rexhepi, A.M., \& Brestovci, B. (2010). The differences in body volume and skinfold thickness between basketball and football players. International Journal of Morphology, 28(4),1069-74.

Saavedra, J. M., Porgeirsson, S., Kristjansdottir, H., Halldorsson, K., Guð mundsdottir, M. L., \& Einarsson, I. P. (2018). Comparison of training volumes in different elite sportspersons according to sex, age, and sport practised. Montenegrin Journal of Sports Science and Medicine, 7(2), 3742. doi: $10.26773 / \mathrm{mjssm} .180906$

Sæther, S. A. (2017). Characteristics of professional and non-professional football players - an eight-year follow-up of three age cohorts. Montenegrin Journal of Sports Science and Medicine, 6(2), 13-8.

Smajic, M., Kuljanin, T., Savic, M., Korac, K., Vasic, G., \& Tomic, B. (2015). The influence of some anthropometric characteristics and motor abilities on agility in young female volleyball players. Sport Mont, 13(43-44-45), 169-175.

Spaic, S., Vukasevic, V., \& Masanovic, B. (2018). Differences in anthropometric characteristics among junior soccer and basketball players. Journal of Anthropology of Sport and Physical Education, 2(4), 89-92. doi: 10.26773/ jaspe.181016

Sprague, P.A., Mokha, G.M., \& Gatens, D.R. (2014). Changes in Functional Movement Screen Scores Over a Season in Collegiate Soccer and Volleyball Athletes. Journal of Strength and Conditioning Research, 28(11) 3155-3163. doi: 10.1519/JSC.0000000000000506

Stanganelli, L.C.R., Dourado, A.C., Oncken, P., Mançan, S., \& da Costa, S.C. (2008). Adaptations on Jump Capacity in Brazilian Volleyball Players Prior to the Under-19 World Championship. Journal of Strength and Conditioning Research, 22(3), 741-749.

Stojanovic, M., Calleja-Gonzalez, J., Mikic, M., Madic, D., Drid, P., Vučković, I., \& Ostojić, S. (2016). Accuracy and Criterion-Related Validity of the 20-M Shuttle Run Test in Well-Trained Young Basketball Players. Montenegrin Journal of Sports Science and Medicine, 5(2), 5-10.

Vukasevic, V., Spaic, S., \& Masanovic, B. (2018). Comparative study of anthropometric measurement and body composition between the basketball player first and second league in Montenegro. Journal of Anthropology of Sport and Physical Education, 2(3),61-65. doi: 10.26773/jaspe.180711

Vukasevic, V., Vukotic, M., \& Masanovic, B. (2018). Comparative study of morphological characteristics and body composition between basketball players from second leagues in Montenegro and Serbia. Journal of Anthropology of Sport and Physical Education, 2(3),21-25. doi: 10.26773/ jaspe. 180704

Vukotic, M., \& Georgiev, G. (2019). Comparative analysis of anthropometric characteristics between athlets of different orientation. Journal of Anthropology of Sport and Physical Education, 3(1), 41-45. doi: 10.26773/ jaspe. 190108

Vukotic, M., \& Georgiev, G. (2019). Comparative analysis of anthropometric characteristics between athlets of different orientation. Journal of Anthropology of Sport and Physical Education, 3(1), 41-45. doi: 10.26773/ jaspe.190108

Zouch, M., Jaffré, C., Thomas, T., Frère, D., Courteix, D., Vico, L., \& Alexandre, C. (2008). Long-term soccer practice increases bone mineral content gain in prepubescent boys. Joint Bone Spine, 75(1), 41-49. 